\title{
Brazilian Public Administration: Shaping and Being Shaped by Governance and Development
}

\author{
Jose A. Puppim de Oliveira ${ }^{1}$
}

Received: 5 October 2016/Accepted: 9 January 2017/Published online: 16 February 2017

(C) Fudan University and Springer Science+Business Media Singapore 2017

\begin{abstract}
This manuscript analyzes the changes in Brazilian public administration and its relation with governance and development trends in the country. The case of the environmental agencies is used to exemplify those changes in the last decades. There are three main modes in the Brazilian public administration: patrimonialism, bureaucratic, and managerial. Even though reforms have taken some effect along the decades, all three modes subsist in different forms in the public organizations. After the democratization of the country, there is a growing influence of civil society in public affairs, but accountability is low. Reforms were carried out by authoritarian and democratic governments from different political spectrums, but the quality of public administration and governance still suffers with components of ineffectiveness in the delivery of public services and patrimonialism, resulting in many recent cases of corruption and mismanagement, as well as the increasing discontent of the population, as shown in the recent protests in Brazil.
\end{abstract}

Keywords Brazil · BRICS - Public administration · Administrative reform · Governance $\cdot$ Development

\section{Introduction: Emerging Challenges in Governance and Development}

There is a lot of emphasis in academia and practice on capacity building and the application of the best practices of public administration (PA) and management to improve public organizations. Public managers and policymakers in Brazil and other BRICS, like in other parts of the world, are continuously pushing for reforms

Jose A. Puppim de Oliveira

jose.puppim@fgv.br; japo3@yahoo.com

1 Fundação Getulio Vargas (FGV), São Paulo School of Management (FGV/EAESP), São Paulo and the Brazilian School of Public and Business Management (FGV/EBAPE), Rio de Janeiro, Brazil 
aiming at improvements in the performance, transparency, and accountability of public administration to deliver quality public services. However, one area that is missing is a critical analysis of the propagation means, the implementation and "impacts" (positive and negative) of Western and Non-Western theories of public administration and management in practice (Gulrajani and Moloney 2012; Ashworth et al. 2013). It is important to better understand the context and the political economy of how and why ideas "travel" from one place to the other, and are applied and changed. There are three dimensions of particular interest for research in Brazil and BRICS in particular, as they are building their own public administrations and at the same time influencing reforms in other countries.

First, one dimension concerns the general decline of trust in public institutions everywhere, which also affects the West (Puppim et al. 2015). Brazil particularly has witnessed a large number of corruption scandals in the last decade. With democratization and reforms, institutions and organizations have been built both in the public sector and civil society for increasing the transparency and accountability of public organizations, but they have not been able to offset the problems of trust in public administration and the political system. The BRICS success internationally will depend how much their governments and public administrations can be trusted at home.

Second, there is a growing interest in the topic of the influence of Western and non-Western PA ideas in developing countries, particularly in Africa and parts of Asia (Haque and Turner 2013). One of the last waves of Western ideas in public administration being exported came under the propagation of New Public Management (NPM) and its mutations. Decentralization has also been propagated primarily by Western organizations (Smoke 2015). However, besides financial resources, BRICS are now influencing and exporting their PA ideas or practices and competing with traditional donors for soft-power. Brazil has been the cradle of innovative ideas like the participatory budgeting and the Bus Rapid Transit (BRT) which have been adopted by hundreds of cities and countries around the world. At the same time, the competition from China/BRICS and other donors (e.g., private foundations, Turkey, Saudi Arabia, and UAE) is influencing the way the traditional donors and intellectual sources of PA knowledge work with governments and academia as well.

Third, there is a rising consensus about the increasing interconnectedness of countries, nations, and societies. New influential actors, such as the BRICS, bring new dynamics to the global institutions. However, public administration and management is still pretty much constrained to think about organizations that are not connected or concerned about what goes on in other parts of the world (except for international relations and development management). The impact of BRICS in world affairs, such as human rights, international terrorism and climate change, implies that changing their public administrations to respond to those issues can make a worldwide difference. The question is then, with the increasing impacts of global problems, will the domestic public administrations become more entrenched in the domestic self-interest (to reach the first class Titanic solution, me first as the safety boat cannot carry everyone)? Or there will be more openness and trust to reform those institutions to think about the global collective interest together? 
The dynamics of the public administration is directly connected to the conceptual ideas that come from different actors. Governments are the main actors to influence public administration in terms of ideas and their execution. However, international organizations have also played a key role in the dissemination public administration ideas using their influence to push for reforms (Brinkerhoff and Brinkerhoff 2015). Public administration systems also reflect what is happening in society. Political, social, economic, and cultural aspects of the context, as well as their changes, have significant impacts on shaping public administration. The political system is particularly important as it shapes who is in control of the State and its relation with society. For example, civil society groups in a democratic system can push for changes on the streets or through the dissemination of ideas.

This paper examines the evolution of the Brazilian public administration along the decades particularly in the last 30 years since the democratization of the country followed by the case of environmental agencies to illustrate the developments in a specific sector. This can bring learning lessons to the BRICS and other developing countries more broadly.

\section{A Short History of the Brazilian Public Administration}

Brazilian public administration started with the organizations developed by the Portuguese colonizers to manage the exploitation of the colony, but a radical change and intensification in building public administration happened when the Portuguese royal family moved to Rio de Janeiro in 1808, running away from the Napoleonic threat in Europe. The Portuguese royals brought large part of their courts and Lisbon public administration to Brazil (around 15,000 all together). Brazil, Rio de Janeiro, in particular, moved from colony to be the center of the kingdom. The State and public administration bureaucracy and processes created roots in the country and continued to develop its own features after the king John VI returned to Portugal in 1821 and Brazil got independence in 1822 .

The history of the Brazilian public administration and State could be summarized in several stages described below (based on Lustosa da Costa and Lustosa da Costa 2016):

- 1808-1822: The roots of a public administration controlled by the Portuguese and under the absolutism of the regime.

- 1822-1840: Building the national State and identity. The independence (Brazil became a Kingdom/Empire by its own) and return of part of the bureaucracy to Portugal brought a need to develop Brazil's own public administration under an absolute State controlled by the Emperor (de jure), but de facto controlled by advisers.

- 1840-1889: Development of a more representative State under the Emperor, with some characteristics of the parliamentarian monarchy. Power over the bureaucracy was decentralized among those taking part of the core political system and public administration was spread beyond the capital (Rio de Janeiro at that time). 
- 1889-1930: The State in the "Old Republic". Brazil became a republic. Patrimonialism as mode of public administration continued from the monarchy, now controlled by a political elite. The public administration used to serve this elite.

- 1930-1945: Building the bureaucratic public administration under the national state controlled by a dictatorship. Getulio Vargas centralized and modernized the state bringing in the main principles of the Weberian administration and professionalization of the public administration, creating the Department of Administration of the Public Service (DASP) and Getulio Vargas Foundation (FGV) to lead the process, but roots of the patrimonialism continued in many practices (Farah 2011, 2016). 'National developmentalism' was the development mode with the creation of national public companies, such as the National Steel Company (CSN).

- 1945-1964: The "national developmentalism" as the philosophy of the state continued after the end of the "New State Era" of Getulio Vargas. State pushed for rapid industrialization and economic development leading to urbanization and the creation of several State companies, such as Petrobras. The capital was moved from Rio de Janeiro to Brasilia (1960).

- 1964-1985: Authoritarian modernization. National developmentalism remained under the military government established in 1964 based on import substitution and a private sector protected by the State. Modernization of public administration continued under authoritarian rule with high degree of centralization.

- 1985-1992: Democratization, neoliberalism and dismantling of the national developmentalism. Economic stagnation and high inflation led to the neoliberal reforms in the public administration, particularly under Collor de Mello government. Government tried to introduce some ideas of the New Public Management reforms along with liberalization of the economy. The Constitution of 1988 gave more responsibilities to states and municipalities leading to political and administrative decentralization and the growth of the public administration in those entities. Civil society organizations started to have more influence in public policies and public administration.

- 1992-2002: The state in the era of the managerialism. The opening the economy continued more gradually. Search for more efficiency and professionalism in the public administration with the attempt of "debureaucratization". Gradual reduction in the number of federal public employees (Nunberg and Pacheco 2016). Several managerial reforms introduced initially in the federal government and later in some states and municipalities (Bresser-Pereira 2009, 2016).

- 2002-2017: National developmentalism returned to the agenda of the federal government. Number of public employees gradually increased. Liberal trends were reversed in the economy, but some of the managerial reforms continued in the federal public administration. In 2016, the president Roussef was impeached and a liberal government of Michel Temer took over the federal government reversing the national developmentalism trends.

There are three main modes in the Brazilian public administration: patrimonialism, bureaucratic, and managerial (Lustosa da Costa 2008). Despite efforts to 
reform, all three continue to subsist together in a certain degree, more or less intense depending on the administrative context. Until 1930, the public administration was controlled by political elites. Public and private interests were mixed in the State actions. Public employees were appointed by political leaders and other influential authorities. The first Getulio Vargas government (1930-1945) made efforts to introduce the bureaucratic and more professional form of public administration that also grew under his dictatorship together with the role of the state in the economy and society. The military dictatorship (1964-1985) consolidated some of the reforms of Vargas, such as a huge state productive apparatus. In the 1980s, the managerial reforms started to take roots and accelerated in the 1990s, but they are still timid for the size of the state. Bureaucratic and patrimonialist forms still dominate the Brazilian public administration.

\section{Recent Reforms}

The transition from military to a civil government in 1980s was fundamental to shape current public administration. The constitution of 1988 devolved power and responsibilities to the states and municipalities. Those started to build further their own public administrations to manage the new responsibilities, such as primary education and health. However, the chaotic economy plagued by hyperinflation in the 1980s and the first half of 1990s (inflation reached almost 2000\% in 1989 and $2500 \%$ in 1993) left little room for making more comprehensive public administration reforms. The reforms pushed by the international organizations linked to the Washington Consensus in 1980s and 1990s, such as privatization and deregulation of public services, aggravated even further the economic situation. Most of the efforts of the administration entities (Union, states, and municipalities) were concentrated on controlling their finances to avoid that their money were eaten by the inflation. The 1992 impeachment of the first president directly elected (Fernando Collor) after the democratization of the country made the situation even more difficult to manage as the political and economic situation was unstable. Nevertheless, the public administrations never collapsed and showed certain degree of resilience to keep up providing certain public services, despite the economic and political problems in the country.

The inflation was controlled in 1994 by the Real Plan, and a new president, Fernando Henrique Cardoso (who was the previous finance minister), was elected giving certain political and economic stability. Under the principles of reducing the role of the state in the economy and promoting the market economy, a series of economic and administrative reforms were carried out mainly at the federal bureaucracy starting in the second half of 1990s. Several state companies were privatized. Cardoso created the Ministry of Federal Administration and Reform of the State (MARE) in 1995 led by Minister Luiz Bresser-Pereira to execute the administrative reforms aimed at improving the efficiency and accountability of the federal bureaucracies. The core of the efforts was the managerial reforms based on some of the principles of the New Public Management (NPM). Administrations were also allowed to outsource certain services to 'social organizations' (NGOs). 
The main impact was the reduction of the budget spent on personnel at the national level. Expenditures with personnel in the federal government as percentage of current net revenues dropped from 55 to 30\% between 1995 and 2003 (Nunberg and Pacheco 2016).

The pace of the reforms slowed down with the incorporation of MARE into the Ministry of Planning in the end of 1990s and the change in the political group governing the country in the end of 2002. The more statist Lula government (2003-2010) halted some of the market reforms and embraced 'developmentalism', promoting a larger role of the State in the economy. He prioritized state led development with a larger role of state companies and scaled up a series of popular social programs (e.g., 'Bolsa Familia', the most known) reducing poverty and inequality in the short term. The number of employees of the federal administration and weight of personnel in the budget increased gradually during Lula's rule. However, some of the previous trends continued, such as outsourcing of certain services to 'social organizations', particularly those with close links to politicians through personal or ideological connections. Nevertheless, managerial reforms continued in some of the states and municipalities. They became common language in the Brazilian administrative environment. Dilma Rouseff's government (2011-2016), who was appointed by Lula to run for president, and succeeded him, kept some of the trends in the Lula's reforms. She made some important reforms in the public employees' pension schemes (for new entrants) reducing longterm budgetary impacts, but the state size continued to grow steadily. Her impeachment in 2016 and the economic crisis in 2014-2015 brought another period of economic and political instability. The new government led by Michel Temer (who was Rouseff's Vice-President) has taken drastic measures to reduce the growing public deficit and new reforms were suggested to make further changes in public employees' pension schemes, alongside the changes in the general social security system (INSS). The former group no longer will have special regime in their pension systems, except for certain groups (e.g., military). Nevertheless, states and municipalities' tax revenues were heavily impacted by the economic crisis, which also showed the problems faced by several subnational entities. Many were not able to reform their public administrations timely and are facing huge challenges.

Together with the managerial administrative reforms, a set of reforms to bring more transparency and accountability to public administrations has taken place in the last two decades. Most of the public budgets are widely open to the public now, including salaries of public employees and travel expenses, for example. Civil society and the press have become more active in denouncing mismanagement and misappropriation of public funds. Moreover, a set of public auditing organizations and prosecutors have grown in scope and size alongside the transparency. More independence of the justice and police has happened as well. Recently, federal and state polices and public attorneys have dismantled several cases of corruption, making accountability reaching all the way to the top of the administrative and political hierarchy, even indicting or arresting some key figures that were 'untouchables' before (e.g., ministers, judges, senators, governors, and including the former president Lula). 
Nevertheless, despite the managerial reforms the bureaucratic and patrimonialistic modes prevail in Brazilian public administration with pockets of managerial modes, more in some organizations than others. In some places, the managerial reforms have never taken effect, and patrimonialism has never left the core of the bureaucracies, being some of the main posts in the public organizations chosen by politics. Signs of meritocracy are still hard to find in some organizations, though, on the other hand, some are completely professionalized.

In the following section, in order to illustrate with a concrete case, I will discuss those issues using the case of the evolution of public administration and governance in the environmental sector in Brazil. This sector is interesting to study public administration and governance as it has evolved rapidly in the last decades and has a strong international component.

\section{The Case of Environmental Agencies}

Over the last 70 years, the landscape of Brazil has undergone rapid transformation, especially along the coast. Cities, ports, and huge industrial clusters have grown up. Agricultural activities have also expanded along the coastal strip and the interior. Logging has advanced toward the few remaining areas of the Atlantic Forest and the Amazon. Cities have boomed in a disorderly fashion. Following infrastructure improvements, the frontier for development has advanced towards the Amazon.

Many of these activities have taken place without proper environmental and landuse planning, causing problems, such as air pollution and water contamination, deforestation, and destruction of officially protected ecosystems, ${ }^{1}$ such as the Atlantic Forest. This forest is thought to have the world's highest tree biodiversity, ${ }^{2}$ but it is located on the coastal areas where most of the population resides. The Atlantic Forest has largely disappeared over the last few decades and just around $8.5 \%$ of its original size is left (SOS Mata Atlantica 2016). Moreover, many traditional communities who live in the forested areas-which house some of the poorest and most powerless people-have been transformed both physically and culturally.

Industrialization, large-scale agricultural production and urbanization have also taken place causing serious problems in terms of air and water pollution, as well as emissions of greenhouse gases (GHGs). At the outset, unrestrained development was not viewed as a problem, since it was occurring in isolated areas and many times incentivized by the public sector, such as the migration to the Amazon or huge industrial complexes. More recently, however, the impacts of this mode of development have spread to larger areas and affected the population significantly, such as the recent droughts in the State of São Paulo in 2015, Brazilian economic

\footnotetext{
1 Many coastal ecosystems, such as dunes and mangroves, are officially protected under the Brazilian federal constitution. However, due to the lack of proper enforcement mechanisms, developers and squatters have occupied and destroyed part of these ecosystems.

2 In 1993, Brazilian scientists and researchers of the New York Botanical Garden announced that they had found the highest tree biodiversity in the world during a field research in the Atlantic Forest in Southern Bahia. More than 450 species of trees were found in one hectare (Conservation International 1995).
} 
hub, which caused water rationing and electricity shortages; or the largest environmental accident in Brazil caused by the collapse of a huge mining debri dam in the state of Minas Gerais. Governmental agencies and some parts of civil society have realized that weak environmental management is a potential threat to the long-term viability of the country, though the public administration and institutions in the environmental sector have not developed at the same pace as the environmental degradation to offset it.

\subsection{Building Public Administration to Address Environmental Matters in Brazil}

Even though there were a series of public environmental interventions along the twentieth century, and some actions, such as the conservationist movement for the creation of national parks started in 1930s, the first federal bureaucracy specialized in environmental matters, the Special Secretariat for the Environment (SEMA), was only created in 1974 during the military government. SEMA came along with the many environmental ministries and agencies around the world established under the influence of the United Nations Conference on Human Environment held in Stockholm in 1972, the first of the large UN conferences on sustainable development (Kraft and Vig 1994). SEMA was a small unit within the Ministry of Interior and had limited organizational capacity. It had little leverage to countervail the developmental pressures, such as the Amazon human occupation and rapid industrialization, promoted by the 'developmental state' in the military regime. However, SEMA played a strategic advisory role to build up the environmental institutions in Brazil. Thus, still during the military rule, under the leadership of SEMA and a group of progressive legislators, the congress approved the Law 6938/81 in 1981 establishing the National Environmental Policy, which was the first comprehensive environmental law shaping the institutions and organizations for managing the environment in the federation. The law instituted the multi-stakeholder National Environmental Council (CONAMA), ${ }^{3}$ which specifies more detailed policy guidelines for implementing federal legislation.

The federal Constitution of 1988 consolidated some of the institutional and organizational changes in the public administration in the environmental area along with other sectors. It states that federal and state governments have the authority to legislate environmental matters in a complementary manner. ${ }^{4}$ The federal government established legislation stating general guidelines and consolidated the first comprehensive federal environmental agency, IBAMA, ${ }^{5}$ by merging SEMA with

\footnotetext{
3 CONAMA (Conselho Nacional do Meio Ambiente) defines national environmental policies through a series of resolutions that are based on federal laws or decrees (for example, CONAMA specifies the limits allowed for air and water pollutants). It is formed by members of the federal government, NGOs and labor and business representatives from the different parts of the country.

4 Article 26, Brazilian Federal Constitution (1988) (Brasil 1988).

5 IBAMA = Instituto Brasileiro do Meio Ambiente e dos Recursos Naturais Renováveis (Federal Environmental Agency). IBAMA is the federal agency that was in charge of the protected areas under federal jurisdiction. IBAMA was divided into two organizations to create the Instituto Chico Mendes for the Conservation of the Biodiversity (ICMBio) in 2007. The latter is in charge of national protected areas and the former enforcement of environmental legislation.
} 
different agencies that dealt with environmental-related issues, like forest and fisheries. Later on, the Ministry of the Environment was established to coordinate the work of IBAMA and other agencies, as well as national policies in the environmental area.

Even though some of the industrialized states, like Rio de Janeiro and São Paulo, had environmental agencies and councils by 1981, there was no comprehensive institutional framework for addressing the problem and dividing the responsibilities before the Law 6938/81. With the law, states then had to organize their own environmental agencies and councils similar to CONAMA and create specific state legislations according to their needs, but must always follow federal guidelines. For example, Bahia State has the State Environmental Council (CEPRAM). ${ }^{6}$ It is a multi-stakeholder advisory body formed by state sectoral agencies, civil society groups, and business and labor unions with proportional membership. It specifies policy guidelines to implement state legislation. CEPRAM exists since 1972 but was consolidated into the state environmental institutions in the aftermath of the Law 6938/81 and the 1988 constitution. CEPRAM members convene regularly to screen important development projects and discuss the introduction of environmental policies based on state laws and decrees. Modernized, with the public given access to its processes, CEPRAM has analyzed an increasing number of projects and polices. The public agency in charge of implementing environmental policies in Bahia is the State Secretariat of the Environment (Secretaria do Meio AmbienteSEMA).

Although the federal constitution does not mention that municipalities can also legislate on environmental matters, it does not stipulate the contrary, and many municipalities have environmental agencies and councils (similar to Bahia). The federal constitution authorizes municipalities to enact legislation to achieve local interests, and these interests have been interpreted to include environmental resource protection (Puppim de Oliveira and Ogata 1998). ${ }^{7}$ However, environmental legislation at lower jurisdictional levels cannot contradict legislation passed at higher levels; that is, municipal legislation cannot be less stringent than state legislation, and state legislation cannot be less stringent than federal legislation.

Regarding land-use rules, which are key for environmental protection, the federal constitution declares that municipalities should promote controlled land occupation through planning, land-use control, land subdivisions, and urban land development rules. The state and federal governments do not directly regulate land use, but they can intervene in land-use rules when environmental protection is involved, such as in the case of environmentally protected areas (APAs) in Bahia (Puppim de Oliveira 2008).

Environmental civil society groups have existed for long time, but the democratization of the country in the 1980s stimulated the creation of several groups (Puppim de Oliveira 2005), especially environmental NGOs. Many of these

\footnotetext{
${ }^{6}$ CEPRAM $=$ Conselho Estadual de Meio Ambiente (State Environmental Council).

7 The Article 30, Brazilian Federal Constitution (1988), states that municipalities can: I-Legislate over any matter of local interest;

II-Supplement federal and state legislation if necessary.
} 
groups were created with specific objectives, such as defending a certain ecosystem or protesting against an environmental problem or disaster. For example, the ProTamar Foundation was created to protect marine turtles, which were threatened almost to extinction by rapid occupation of the seashore. ${ }^{8}$ The Movement for the Defense of Sao Francisco River (MDSF) was established to mobilize the local population regarding environmental problems in the river, such as pollution and sedimentation. Most of these NGOs act regionally or locally. Only few have links to NGOs in other states or countries, except the multinational NGOs, such as Greenpeace or Conservation International. However, NGOs are also important in environmental decision-making. Some of them regularly denounce environmental degradation and actively participate in the decisions of the federal and state environmental decision bodies, such as CONAMA and CEPRAM.

One interesting innovation in public administration for environmental protection is the establishment of the environmental public prosecutors. Their job is to protect collective and public interest, such as the environmental protection. Created by the 1988 constitution, public prosecutors have played a key role to start legal actions against any person or organization, including public administrations, involved in environmental degradation. They can sue a developer for forest clearing above the law limits and the environmental agency for not enforcing the law. Their active involvement in many states together with civil society has pushed for more accountability and transparency in public administration.

Since the nation's democratization in 1985, actors in civil society, such as nongovernmental organizations (NGOs) and community organizations, have increasingly pressured governmental authorities to take greater responsibility for protecting environmental resources and the well-being of communities. For example, in the coastal village of Balbino in the state of Ceara, developers burned houses and threatened villagers with death to force them from their land, which was partially covered by mangroves. With the support of NGOs, communities highlighted these issues in the mainstream media and pressured local and state authorities to take action to protect local people and award them title to the land. In the end, state government legalized local land titles and created an environmentally protected area (APA) in the region to avoid land speculation. The participation of local organizations has also been important to enforce the law and implement environmental policies (Puppim de Oliveira 2005, 2002). In Bahia, local inhabitants in Abaete APA denounced a construction project that violated APA guidelines and tried to stop it in court, even though developers had a municipal construction permit (Tarde 1998; Ministério Público Federal 1997).

Global concerns, such as climate change and biodiversity, have also permeated public administrations at the different levels. Brazil has ratified most of the multilateral environmental agreements (MEAs). Different units of the Ministry of the Environment deal with global environmental issues. The national congress enacted the Law 12.187 in 2009 creating the National Policy on Climate Change

\footnotetext{
${ }^{8}$ It has government support through links with the ICMBio and the Brazilian state oil company (Petrobras). Pro-Tamar Foundation has successfully expanded its activities over the years. Today, it acts in several coastal states.
} 
(NPCC). States and some municipalities have also built their institutions and organizations to manage climate change adaptation and mitigation. Some of them, such as the State of Sao Paulo, have established their climate change policy laws and institutions to deal with climate change even before the national government (Puppim de Oliveira and Andrade 2016). State public administrations, like the national government, also interact with each other and the international organizations to exchange information and build up their capacity, even though there are mismatches in the interests and implementation priorities among organizations (Puppim de Oliveira 2014).

The mere identification of a problem is rarely sufficient to spur determined State and public administration action. There have been several obstacles to expand state government role in environmental protection. Like in other sectors, the decentralization envisioned in the 1988 constitution and the National Environmental Policy Law has been undermined by the lack of resources at the subnational level. Building capacities in the public administration for environmental protection has been uneven among states and municipalities. Some entities have built strong and effective apparatus, but others have lacked behind (Puppim de Oliveira 2005). Although municipalities control land use according to the federal constitution, many municipalities have no institutional apparatus to implement land-use controls. In Bahia, among more than 400 municipalities, only the capital Salvador had prepared a master plan in 1999. Furthermore, federal and state governments issued environmental legislation specifying land-use rules that municipalities were supposed to follow, such as coastal management plans. However, many municipalities had different land-use regulations or lack the institutional apparatus to implement these upper-level regulations, so they rarely follow them.

Managerial reforms have not had significant impacts on the public administrations in the environmental sector. Bureaucratic modes still predominates, as most of the activities are regulated. In addition, corruption scandals and patrimonialism are also common in the public administration in the environmental sector. There have been many cases of unethical behavior of environmental officials involving illegal logging and bribes to issue licenses. In a recent case, the head of the environmental agency and ministry of fisheries in one state were arrested by the federal police as they were trying to sell fishing licenses for fishing companies (O Globo 2015). The head of the agency was appointed by a political party in power.

\section{Trends and Challenges in the Brazilian Public Administration}

There are a number of trends in the Brazilian public administration similar to those shown in the case of the environmental sector. I will pinpoint some of the most prominent ones. First, the Brazilian public administration has changed drastically in the last two decades and has gradually interacted more with civil society. The shape of public administrations and the way they implement public policies in Brazil is largely affected by the regime and party in power, but some trends do not stop with changes in governments. For example, since the democratization of the country in 1980 s, civil society groups have gained political power and are gradually able to 
influence public policies, both policy-making and implementation, such as in the environmental area. NGOs and social movements are also influential in several other areas of public policy, such as housing and agrarian reform. Innovative participatory processes have taken place in several instances of decision-making from consultation to direct decision vote. The participatory budgeting, which started in Porto Alegre, is one of those innovations that have now been spread to several countries (Cabannes 2004).

Second, there is an increasing concentration of financial and human resources at the federal level, though the bulk of services is in the hands of states and municipalities. The constitution of 1988 aimed at political and administrative decentralization and gave autonomy and power to states and municipalities, but they face increasing challenges to deliver quality public services. Even though the constitution and other reforms aimed at decentralization, most of the public budget stay at the federal level. In 2014, the federal, state, and municipal levels had, respectively, 68.5, 25.3, and 6.2\% of the total government taxes (Receita Federal 2015). States and municipalities now deliver the bulk of public services but are strangled financially. Most of the municipalities do not have their own revenues and depend largely from transfers form the federal and state governments. Moreover, even though all municipalities have the same responsibilities, there is a huge difference in administrative and financial resources among them (the same for the states), both in terms of quality and quantity. There are very different municipalities, like São Paulo city ( 12 million inhabitants) and Borá (825 inhabitants), both with the same constitutional responsibilities. As their sizes and capacities vary significantly, this leads to an unequal capacity to delivery public services effectively, such as health and education (Avallaneda and Gomes 2015). There are also some conflicts of jurisdiction over certain responsibilities (Puppim de Oliveira 2005).

Third, the bureaucracy has several urgent problems to be addressed right away. The size of the State has grown but not the quality of public services. Although the number of employees at the federal level has not changed significantly in the last decade, the amount of the revenues to cover personnel costs have steadily increased. Moreover, the numbers of employees at the municipal and state level, and the costs of public machines, have grown drastically since 1988. Tax revenues account for $34.4 \%$ of the Brazilian GDP (Higgins and Pereira 2014). Allied to the financial mismanagement, the recent crises in public administration have shown evidence that a urgent reform in the public administration is needed. Public services have deteriorated. Many states are financially broken and cannot even pay their employees, such as the case of the State of Rio de Janeiro, which had not paid its employees' October salary in December in 2016. Various other states have signaled that they will face the same situation as Rio's soon. Despite that mismanagement and corruption were problematic in many cases, the core reasons for the financial problems are the expansion of the activities of the state and municipalities without proportional growth in revenues and reforms to improve the efficiency of the public bureaucracies.

Finally, the issues of ethics in politics, government and public administration have also continued to be a major problem in the Brazilian State. Despite all the 
reforms to professionalize public administration, patrimonialism still rules many public organizations and contracts. There are 350,000 jobs (out of 1.1 million public employees in total) filled by political appointments at the federal level costing more than US\$ 1 billion per month (O Globo 2016). If you include states and municipalities, this number can easily double. Most of the top managerial posts in public administration in all three levels are filled by political appointments. Many are appointed by political parties under their 'quota' in exchange for political support for the government. Distribution of jobs by political appointments is key in a fragmented political system, where the federal parliament has more than 25 parties represented. Individual and political interests influence many of the administrative decisions. Thus, it is not a surprise cases of corruption and mismanagement of state companies and other organizations, almost always involving political appointees. This has been routine in the Brazilian public administration, reducing the trust among the population. Nevertheless, there is a growing institutional capacity in the State and civil society to push for transparency and accountability in the last decades, which has kept a system of check and balances of public officials, though not enough to avoid many of the corruption scandals.

\section{Conclusions}

The organizational aspects of public administration are fundamental for its effectiveness in providing the services to society. However, they are important but not determinant to guarantee the good functioning of public administration and the quality of public services, as public administration alone does not control society or government, and vice versa. The interactions between the public organizations and other actors are determinant of the way society functions, and services and goods are delivered, such as in the case of Brazil. These interactions happen through the formal political system or through stakeholder engagement.

Reforms to strengthen the interaction of civil society and public administrations can address some of the aspects mentioned in the introduction. Civil society interests have grown in many developing countries, such as Brazil and BRICS in general. They have also allies in the media and inside the governments that connect them to the formal political and administrative system. They can help to improve trust, to adapt external ideas to the local context, and address the increasing number of global issues. Civil society groups have disseminated new values in society and also bringing their interests and values to decision-making processes. They have campaigned for and against many causes that can potentially affect the diffusion of knowledge in society and the public administration, such as in the environmental sector. In addition, many people who work for civil society organizations can later work for governmental organizations, contributing for the introduction of their values and ideas in these organizations.

Brazilian public administration has evolved rapidly in the last decades, particularly since the democratization of the country in 1980s. Several reforms have been introduced by different governments at the three levels of government 
along the history. The size of the public sector has grown significantly, but the situation of the provision of quality public services is still limited and cases of corruption and mismanagement in the public sector pop up almost daily. On the one hand, managerial and organizational reforms have room to enhance the performance of the public sector. Areas, such as human resource and financial management, are still problematic (Nunberg and Pacheco 2016). However, reforms alone will not change much without significant improvements in the political system and governance, though governance has improved to bring more accountability to the public sector, but not enough to increase the quality of the public services or trust in public organizations. Thus, international networks, such as BRICS, can be an avenue for exchange of experiences and capacity building, but also develop peer-to-peer accountability mechanisms to raise the bar of governance in Brazil and the other countries to address the old and new challenges of public administration.

Acknowledgements This research was supported by a grant from the Dr. Seaker Chan Center for Comparative Political Development Studies at Fudan University.

\section{References}

Ashworth, R., E. Ferlie, G. Hammerschmid, M.J. Moon, and T. Reay. 2013. Theorizing contemporary public management: international and comparative perspectives. British Journal of Management 24 (S1): S1-S17.

Avellaneda, C.N., and R.C. Gomes. 2015. Is Small Beautiful? Testing the Direct and Nonlinear Effects of Size on Municipal Performance. Public Administration Review 75 (1): 137-149.

Brasil. 1988. Constituição Federal.

Bresser-Pereira, Luiz Carlos. 2016. Reforma Gerencial e legitimação do Estado Social. FGV/EESP, manuscrito.

Bresser-Pereira, L.C. 2009. Os primeiros passos da reforma gerencial do Estado de 1995. Novos Caminhos da Gestão Pública: Olhares e Dilemas. Rio de Janeiro: Qualitymark.

Brinkerhoff, D.W., and J.M. Brinkerhoff. 2015. Public sector management reform in developing countries: Perspectives beyond NPM orthodoxy. Public Administration and Development 35 (4): 222-237.

Cabannes, Y. 2004. Participatory budgeting: a significant contribution to participatory democracy. Environment and Urbanization 16 (1): 27-46.

Conservation International. 1995. The Economics of Biodiversity: Conservation in the Brazilian Atlantic Forest. Washington, D.C.: Conservation International.

Farah, M.F.S. 2016. Formação em política pública no Brasil. Das iniciativas pioneiras dos anos 60 à institucionalização do "campo de públicas”. Estudios Políticos 49: 192-215.

Farah, M.F.S. 2011. Administração pública e políticas públicas. Revista de Administração Pública (RAP) 45 (3): 813-836.

Gulrajani, N., and K. Moloney. 2012. Globalizing Public Administration: Today's Research and Tomorrow's Agenda. Public Administration Review 72 (1): 78-86.

Haque, M.S., and M. Turner. 2013. Knowledge-Building In Asian Public Administration: An Introductory Overview. Public Administration and Development 33 (4): 243-248.

Higgins, S., and C. Pereira. 2014. The effects of Brazil's taxation and social spending on the distribution of household income. Public Finance Review 42 (3): 346-367.

Kraft, Michael E., and Norman J. Vig. 1994. Environmental Policy from 1970s to 1990s: Continuity and Change. In Environmental Policy in the 1990s, ed. Norman J. Vig, and Michael E. Kraft. Washington, D.C.: CQ Press.

Lustosa da Costa, F. 2008. Brasil: 200 anos de Estado; 200 anos de administração pública; 200 anos de reformas. Revista de Administração Pública 42 (5): 829-874. 
Lustosa da Costa, F., and E.M. Lustosa da Costa. 2016. Nova história da administração pública brasileira: pressupostos teóricos e fontes alternativas. Revista de Administração Pública 50 (2): 215-236.

Ministério Público Federal, Procuradoria da Bahia. 1997. Relatório ao Juiz Federal da $3{ }^{-}{ }^{2}$ Vara Federal da Bahia. December 12. Salvador, Brazil.

Nunberg, B., and R.S. Pacheco. 2016. Public Management Incongruity in 21st Century Brazil. New Order and Progress: Development and Democracy in Brazil, ed. B.R. Schneider, pp. 134-161. Oxford: Oxford University Press.

O Globo Newspaper. 2016. Cargos de confiança custam R \$ 3,5 bi por mês, aponta TCU. 27 May 2016. Accessed on 30 October 2016. http://oglobo.globo.com/brasil/cargos-de-confianca-custam-35-bipor-mes-aponta-tcu-19383152\#ixzz4SEDNOQ2k.

O Globo Newspaper. 2015. Número 2 da pesca e chefe do Ibama em SC são presos pela PF. Accessed on 30 October. http://oglobo.globo.com/brasil/numero-2-da-pesca-chefe-do-ibama-em-sc-sao-presospela-pf-17780634\#ixzz4SIFEHdkf.

Puppim de Oliveira, J.A., and C. Andrade. 2016. The Political Economy of Clean Energy Transitions at Sub-national Level: Understanding the Role of International Climate Regimes in Energy Policy in Two Brazilian States. UNU-WIDER Working Paper, Helsinki.

Puppim de Oliveira, J.A., Yijia Jing, and Paul Collins. 2015. Public Administration for Development: Trends and the Way Forward. Public Administration and Development 35 (2): 65-72.

Puppim de Oliveira, J.A. 2014. The Mismatch of Implementation Networks in International Environmental Regimes: Lessons from Different Agreements. Best Practices for Architecture and Agency. In: Improving Global Environmental Governance: Best Practices for Architecture and Agency, ed. N. Kanie, P.M. Haas and S. Andersen, S., pp. 108-129. New York: Routledge.

Puppim de Oliveira, J.A. 2008. Implementation of Environmental Policies in Developing Countries. Albany: StateUniversity of New York-SUNY Press.

Puppim de Oliveira, J.A., and Maria G. Ogata. 1998. Análise Institucional da Gestão e Uso do Solo nas Áreas Protegidas no Estado da Bahia. Análise \& Dados 8 (2-3): 89-97.

Puppim de Oliveira, J.A. 2005. Enforcing Protected Area Guidelines in Brazil: What Explains Participation in the Implementation Process. Journal of Planning Education and Research 24 (4): 420-436.

Puppim de Oliveira, J.A. 2002. Implementing Environmental Policies in Developing Countries through Decentralization: The Case of Protected Areas in Bahia, Brazil. World Development 30 (10): 1713-1736.

Receita Federal. 2015. Carga Tributária no Brasil—2014 (Análise por Tributo e Bases de Incidência). Brasilia: Receita Federal.

Smoke, P. 2015. Rethinking decentralization: Assessing challenges to a popular public sector reform. Public Administration and Development 35 (2): 97-112.

SOS Mata Atlantica 2016. Website accessed on 08 August 2016: https://www.sosma.org.br/nossa-causa/ a-mata-atlantica/.

Tarde, A. 1998. Manifestantes fazem ato em defesa de dunas. A Tarde newspaper, January 19, p. 8.

Jose A. Puppim de Oliveira is a faculty member at the Getulio Vargas Foundation (FGV/EAESP and FGV/EBAPE). His research examines patterns of governance, institution building, and policy implementation at different levels, looking at how global and national institutions are interlinked to local governance and action. 